\section{REFERENCES}

1. Cherry JD, Brunell PS, Golden GS, Karzon DT. Report of the task force on pertussis and pertussis immunization-1988. Pediatrics 1988;81(suppl):939-984.

2. Cherry JD. The epidemiology of pertussis and pertussis immunization in the United Kingdom and the United States. A comparative study. Curr Probl Pediatr 1984;14:1-78.

3. Centers for Disease Control. Immunization Practices Advisory Committee. Diphtheria, tetanus, and pertussis: recommendations for vaccine use and other preventive measures-recommendations of the ACIP. MMWR 1991;40(No.RR-10):1-28.

4. Christie CDC, Marx ML, Marchant CD, Reising SF. The 1993 epidemic of pertussis in Cincinnati. N Engl J Med 1994;331:1621.

5. Rosenthal S, Strebel P, Cassiday P, Sanden G, Brusuelas K, Wharton M. Pertussis infection among adults during the 1993 outbreak in Chicago. J Infect Dis 1995;171:1650-1652.

6. Bass JW, Stephenson SR. The return of pertussis. Pediatr Infect Dis J 1987;6:141-144.

7. Fine PED, Clarkson JA. The recurrence of whooping cough: possible implications for assessment of vaccine efficacy. Lancet 1982;1:666-669.

8. Wright SW, Edwards KM, Decker MD, Zeldin MH. Pertussis infection in adults with persistent cough. JAMA 1995;13:10441046.

9. Mink C, Cherry JD, Christenson P, et al. A search for Bordetella pertussis infection in university students. Clin Infect Dis 1992;14:464-471.

10. Deville JG, Cherry JD, Christenson PD, et al. Frequency of unrecognized Bordetella pertussis infections in adults. Clin Infect Dis. In press.

11. Cherry JD, Beer T, Chartrand SA, et al. Comparison of antibody values to Bordetella pertussis antigens in young German and American men. Clin Infect Dis 1995;20:1271-1274.

12.Schmitt-Grohé S, Cherry JD, Heininger U, Überall M, Pineda E, Stehr K. Pertussis in German adults. Clin Infect Dis. In press.

13. Kurt TL, Yeager AS, Guenette S, Dunlop S. Spread of pertussis by hospital staff. JAMA 1972;221:264-267.

14. Shefer A, Dales L, Nelson M, Werner B, Baron R, Jackson R. Use and safety of acellular pertussis vaccine among adult hospital staff during an outbreak of pertussis. J Infect Dis 1995; 171:1053-1056.

15.Linneman CC, Ramundo N, Perlstein PH, Minton SD, Englender GS. Use of pertussis vaccine in an epidemic involving hospital staff. Lancet 1975;11:540-543.

\title{
New TB Respirators Expected to Save Millions
}

\section{by Gina Pugliese, RN, MS, Medical News Editor}

\section{From NIOSH}

The National Institute for Occupational Safety and Health (NIOSH) announced that it has certified the first 13 respirators under its new testing and certification requirements (Federal Register June 8, 1995:30338). The price estimates for this first round of respirators-some as low as $\$ 1$-should mean considerable savings for the healthcare industry. "The tremendous decrease in cost is welcome news," said Human Health Services Secretary Donna E. Shalala. "In a time when regulatory actions are frowned upon, this is an excellent example of how a smart regulation can lead to considerable savings."

The new regulations, which became effective July 10, 1995, allow for a generation of respirator filters with less leakage, more efficiency, and easier breathing. Before the new regulation, the only respirator that met the filtration efficiency performance criteria outlined by the $\mathrm{CDC}$ for the prevention of tuberculosis cost approximately $\$ 8$. The first 13 respirators certified under the new rule will range in price from less than $\$ 1$ to $\$ 3$, according to the manufacturers. All respirators certified by NIOSH under the new regulations will meet or exceed the $\mathrm{CDC}$ filtration efficiency performance criterion.

The exact savings to the healthcare industry cannot be predicted with certainty. However, a recent cost analysis of the 159 acute care inpatient Department of Veterans Affairs (VA) facilities in the US suggests that the VA alone may save up to $\$ 16$ million annually. Given that the VA system only represents a small percentage of all hospital beds in the US, the savings nationwide could be extraordinary.

NIOSH Director Dr. Linda Rosenstock said, "We are thrilled with the impact of this regulation. Working closely with industry and employee representatives has resulted in better protection for workers and increased savings for industry. It is no surprise that this activity was recognized by Vice President Gore with a Hammer Award for its impact on redesigning government."

The first 13 respirators certified under the new regulations were chosen randomly from the submissions received before the July 7, 1995, deadline. NIOSH currently is working to certify another 120 respirators awaiting approval. For information on the newly certified respirators, contact NIOSH at (800) 35-NIOSH.

\section{From OSHA}

On September 6, 1995, the Occupational Safety and Health Administration (OSHA) issued an updated enforcement policy for occupational exposure to tuberculosis in response to the recently revised NIOSH certification criteria. OSHA will accept the N-95 respirator, which meets the CDC criteria for respiratory protection, as the minimum level of respiratory protection for $\mathrm{TB}$. The $\mathrm{N}$ 95 respirators also must be able to be (1) fit tested to obtain a face-seal leakage of less than $10 \%$; (2) fit different facial sizes and characteristics; and (3) be able to be checked for face piece fit each time the respirator is put on. OSHA also will allow reuse of disposable respirators as long as the respirator maintains its functional and structural integrity. Each facility must have a protocol for the circumstnaces in which a respirator will be considered contaminated and not to be reused. OSHA notes that if a faciity chooses, they may continue to use HEPA respirators.

FROM: NIOSH. NIOSH change will save healthcare industry millions. Press release, August 25, 1995.

OSHA. Update: OSHA enforcement policy for occupational exposure to tuberculosis. Memorandum, September 6, 1995. 